\title{
Bulgarian Language
}

National Cancer Institute

\section{Source}

National Cancer Institute. Bulgarian Language. NCI Thesaurus. Code C153869.

An Indo-European language, a member of the Southern branch of the Slavic language family. 